\title{
PENGARUH PEMBELAJARAN BERBANTUAN MEDIA BERBASIS KOMPUTER TERHADAP KOMPETENSI SISWA MEMBUAT POLA DI SMKN 6 YOGYAKARTA
}

\author{
Laila Nurul Himmah \\ SMK Negeri 6 Yogyakarta \\ lailanurulh@gmail.com \\ Moch. Bruri Triyono \\ Universitas Negeri Yogyakarta \\ bruritriyono@yahoo.co.id
}

\begin{abstract}
Abstrak
Penelitian ini bertujuan untuk mengetahui perbedaan pencapaian kompetensi siswa membuat pola menggunakan pembelajaran berbantuan media adobe flash dan media power point berdasarkan kemampuan belajarnya pada mata diklat membuat pola. Penelitian ini merupakan penelitian quasi eksperimen dengan variabel terikat kompetensi siswa, variabel bebas media berbasis komputer, dan variabel moderator kemampuan siswa. Dua kelas sebagai subyek penelitian dengan 22 siswa pada masing-masing kelas, sehingga jumlah keseluruhan 44 siswa. Instrumen yang digunakan berupa lembar penilaian unjuk kerja dan soal post test. Data dianalisis dengan menggunakan uji Anova jalur ganda dan uji lanjut Tukeys. Hasil penelitian menunjukkan bahwa (1) terdapat perbedaan pencapaian kompetensi siswa membuat pola yang menggunakan pembelajaran berbantuan media adobe flash dan media power point, (2) terdapat perbedaan pencapaian kompetensi siswa pada kelompok tinggi, (3) tidak terdapat perbedaan pencapaian kompetensi siswa pada kelompok rendah, dan (4) terjadi interaksi antara penggunaan media berbasis komputer dan kelompok kemampuan siswa terhadap kompetensi siswa membuat pola.
\end{abstract}

Kata Kunci: media berbasis komputer, kemampuan siswa, kompetensi membuat pola

\section{THE EFFECT OF LEARNING THROUGH COMPUTER-BASED MEDIA ON THE COMPETENCY IN PATTERN MAKING STUDENTS OF SMKN 6 YOGYAKARTA}

\begin{abstract}
This study aimed to investigate difference in the attainment of the student competency in pattern making that using learning strategies Adobe Flash media and Power Point media based on the learning capability of the pattern making. This was a quasi-experimental study involving student's competency as the dependent variable, computer-based media as a independent variable, and student's capability as the moderator variable. Two class as research subjects with 22 students in each class, so that the total was 44 students. The instruments were a performance assessment sheet and a post-test. The data were analyzed by means two-way ANOVA and Tukey's post-hoc test. The results of study show that (1) there was a difference in the attainment of the students competency in pattern making that using learning strategies Adobe Flash media and Power Point media, (2) there was a difference in the attainment of the students competency in the upper group learning, (3) there was no difference in the attainment of the students competency in the lower group learning, and (4) there was an interaction of the use of computer-based media and the student learning capability group on the students competency in pattern making.
\end{abstract}

Keywords: computer-based media, student's capability, competency of pattern making 


\section{PENDAHULUAN}

Pendidikan kejuruan adalah bagian dari sistem pendidikan yang mempersiapkan siswa agar mampu bekerja dalam bidang tertentu. Pada satuan pendidikan menengah, Sekolah Menengah Kejuruan (SMK) memiliki tujuan untuk meningkatkan kecerdasan, pengetahuan, kepribadian, ahklak mulia, serta keterampilan untuk hidup mandiri dan mengikuti pendidikan lebih lanjut sesuai dengan kejuruannya. Diharapkan lulusan SMK mampu memenuhi tuntutan tenaga kerja yang kompeten dalam rangka peningkatan produktivitas dan efisiensi serta mampu bersaing pada pasar tenaga kerja internasional di era globalisasi.

Peran SMK sebagai penyedia tenaga kerja tingkat menengah, menurut penjelasan UU Sisdiknas no 20 tahun 2003 pasal 15 tujuan SMK adalah mempersiapkan siswa agar mampu: (a) bekerja baik secara mandiri atau mengisi lowongan pekerjaan yang ada sebagai tenaga kerja tingkat menengah, sesuai dengan keahlian dan ketrampilannya, (b) memilih karir, ulet dan gigih dalam berkompetensi dan mengembangkan sikap profesional dalam bidang keahlian yang diminatinya, dan (c) mengembangkan diri di kemudian hari melalui jenjang pendidikan yang lebih tinggi.

Sebagai konsekuensi dari tujuan tersebut yaitu lulusan SMK harus memenuhi standar kompetensi lulusan sehingga secara kualitas mampu memenuhi tuntutan dunia usaha dan industri sesuai bidang keahlian masing-masing serta mampu mengembangkan sikap profesional. Standar kompetensi yang harus dicapai siswa SMK dilaksanakan melalui pembelajaran yang bersifat ketrampilan. Berkaitan dengan hal ini upaya peningkatan kualitas pembelajaran perlu dilaksanakan dengan berbagai terobosan baru yang berkenaan dengan pembelajaran.

Dalam Peraturan Pemerintah (PP) tentang Standar Nasional Pendidikan pasal 19 ayat (1) dinyatakan bahwa proses pembelajaran pada satuan pendidikan diselenggarakan secara interaktif, inspiratif, menyenangkan, menantang, memotivasi siswa untuk berpartisipasi aktif, serta memberikan ruang yang cukup bagi prakarsa, kreativitas dan kemandirian. Guru sebagai ujung tombak dalam pencapaian tujuan pendidikan perlu memilih strategi pembelajaran yang efektif dan efisien. Pemilihan dan penerapan strategi pembelajaran yang tepat harus disesuaikan dengan tujuan dan karakteristik mata pelajaran serta kondisi siswa.

Bidang keahlian Busana Butik memiliki program pembelajaran yang membekali siswa dengan keterampilan, pengetahuan dan sikap agar kompeten dalam hal: menggambar busana, membuat pola, membuat busana, memilih bahan baku busana, membuat hiasan pada busana, dan mengawasi mutu busana, yang kesemuanya itu termasuk dalam mata diklat produktif. Salah satu mata diklat pada program studi ini yaitu mata diklat Membuat Pola yang diajarkan pada siswa SMK N 6 Yogyakarta kelas XI. Materi pada mata diklat ini berbentuk teori dan praktek. Tujuan diajarkannya mata diklat Membuat Pola agar siswa mampu menguraikan macam-macam pola dan mampu membuat macam-macam pengembangan pola sesuai desain dengan baik dan benar.

Berdasarkan hasil observasi awal dan wawancara dengan guru pengampu mata diklat Membuat Pola di SMK N 6 Yogyakarta, cara guru mengajar masih konvensional dan guru hanya menggunakan media pembelajaran modul atau jobsheet dibantu power point untuk beberapa pertemuan. Ditemukan bahwa materi membuat pola merupakan materi yang dianggap cukup sulit oleh siswa, hal ini ditunjukkan dari hasil kompetensi siswa yang kurang memuaskan karena masih banyak yang di bawah kriteria ketuntasan minimal.

Menurut hasil wawancara dengan beberapa siswa, diketahui bahwa mereka masih kurang jelas dan kurang termotivasi dalam mengerjakan tugas yang diberikan, ada juga yang membuat pola asal jadi saja, hal itu dikarenakan siswa kurang memahami langkahlangkah pembuatan pola yang cukup rumit. Media pembelajaran yang digunakan sebenarnya sudah tepat, yakni menggunakan modul membuat pola. Namun media tersebut kurang menarik perhatian siswadan kurang memberikan kejelasan pemahaman materi kepada siswa.

Salah satu faktor kegagalan pembelajaran adalah adanya berbagai jenis hambatan dalam proses komunikasi antara siswa dan 
guru karena variasi dalam pengajaran serta jarang digunakannya alat bantu lain yang dapat memperjelas pemahaman siswa tentang materi yang dipelajari. Untuk itu diperlukan strategi pembelajaran lain yang menarik dan memudahkan siswa untuk memahami proses membuat pola sesuai desain yakni dengan membuat terobosan baru pada proses pembelajaran ketrampilan. Di sisi lain sesuai dengan sifat pembelajaran ketrampilan, evaluasi yang tepat apabila dilaksanakan dengan model evaluasi kinerja, sementara yang sudah dilaksanakan hanya berdasarkan evaluasi produk, sehingga sulit diketahui pada bagian mana siswa kurang memahami ketrampilan dari kompetensi yang seharusnya dikuasai.

Seiring dengan kemajuan teknologi di bidang elektronik dan bidang komputer, menuntut dan mendorong penggunanya untuk diterapkan pada sistem pendidikan di Indonesia. Ditambah lagi pada saat sekarang sedang digalakan dan dikembangkan media pembelajaran berbasis komputer. Aplikasi komputer dalam pembelajaran memungkinkan berlangsungnya proses belajar yang efektif dan efisien ditinjau dari segi waktu dan pencapaian materi. Komputer memiliki kemampuan dalam mengintegrasikan komponen teks, warna, suara, musik, dan animasi grafik.

Selain penggunaan media adobe flash untuk pembelajaran yang memperlihatkan proses kinerja, didalam proses pembelajaran hendaknya memperhatikan perbedaan-perbedaan individual siswa paling tidak dengan mengetahui kelompok siswa berkemampuan awal tinggi dan rendah. Sehingga pembelajaran benarbenar dapat merubah kondisi siswa dari yang tidak tahu menjadi tahu, dari yang tidak paham menjadi paham serta dari yang berperilaku kurang baik menjadi berperilaku baik. Di sini tugas guru harus bisa menyiasati keadaan tersebut, penguasaan suatu proses pembelajaran merupakan salah satu tugas yang harus dilakukan oleh seorang guru, guru dituntut aktif dan kreatif.

Pembelajaran merupakan suatu proses belajar mengajar yang terdiri dari kombinasi dua aspek, yaitu belajar yang dilakukan oleh siswa dan mengajar yang dilakukan oleh guru sebagai pendidik (fasilitator).
Menurut Nitko \& Brookhart (2007,p.18) menyatakan: "instruction is the process you use to provide students with the conditions that help them achieve the learning targets". Pembelajaran adalah proses yang pendidik gunakan untuk membentuk siswa dengan kondisinya serta membantu mereka mencapai tujuan belajar.

Billett (2011, p.5) menyatakan bahwa:

Educational concerns include finding ways of assisting individuals in identifying the occupation to which they are suited, the initial development of capacities required for that occupation, and then, the refinement of those capacities and their ongoing development throughout working lives and in ways to sustain employability.

Berdasarkan pernyataan di atas, pendidikan kejuruan difokuskan untuk membantu individu dalam mengidentifikasi pekerjaan yang cocok, pengembangan awal kemampuan yang dibutuhkan untuk bekerja, membangun kemampuan atau kompetensi yang dibutuhkan untuk pekerjaan yang dipilih serta pengembangan kompetensi secara berkelanjutan.

Pembelajaran yang efektif memerlukan lingkungan belajar yang mendukung siswa menjadi pembelajar yang aktif sebagai subyek utama dalam proses belajar untuk mencapai hasil belajar. Dalam konteks pembelajaran kejuruan, Lucas et.al. (2012, p.60) menyatakan bahwa:

Consistently good vocational education learning environments are full of opportunities for feedback, both from the 'teacher' and, increasingly, from the vocational learner as he or she becomes more and more self-aware and adept at noticing what is going on as he or she learns.

Berdasarkan pernyataan di atas, siswa merupakan pembelajar yang aktif mencari pengetahuan dan pemahamannya. Oleh karena itu, lingkungan belajar dalam pendidikan kejuruan perlu memberikan kesempatan umpan balik, baik dari guru maupun dari siswa sehingga siswa menyadari kemampuan, serta kemahirannya dalam belajar.

Dengan demikian pembelajaran kejuruan memerlukan perencanaan pembelajaran yang 
matang yakni pada desain instruksional yang berisikan komponen-komponen pembelajaran, termasuk pemilihan strategi pembelajaran yang tepat dan media pembelajaran yang menarik, sehingga dapat meningkatkan motivasi siswa, merangsang pikiran, dan dapat mendorong terciptanya proses belajar yang maksimal pada diri siswa.

Berlangsungnya proses pembelajaran tidak terlepas dari komponen-komponen pembelajaran yang terdapat pada Desain Instruksional. Desain Instruksional menurut Dick and Carey (2006, pp.6-8) terdiri dari beberapa komponen, yakni tujuan pembelajaran, materi pembelajaran, evaluasi pembelajaran dan strategi pembelajaran.

Upaya merumuskan tujuan pembelajaran dapat memberikan manfaat tertentu, baik bagi guru maupun siswa. Sukmadinata (2002, p.38) mengidentifikasi 4 manfaat dari tujuan pembelajaran, yaitu: (a) memudahkan dalam mengkomunikasikan maksud kegiatan belajar mengajar kepada siswa, sehingga siswa dapat melakukan perbuatan belajarnya secara lebih mandiri, (b) memudahkan guru memilih dan menyusun bahan ajar, (c) membantu memudahkan guru menentukan kegiatan belajar dan media pembelajaran, dan (d) memudahkan guru mengadakan penilaian

Secara garis besar dapat dikemukakan bahwa materi pembelajaran (instructional materials) adalah pengetahuan, keterampilan, dan sikap yang harus dikuasai siswa dalam rangka memenuhi standar kompetensi yang ditetapkan. Menurut Sanjaya (2006, p.58) materi merupakan inti dalam proses pembelajaran.

Menurut Sudjana (2009, p.3) evaluasi merupakan proses memberikan atau menentukan nilai kepada objek tertentu berdasarkan suatu kriteria tertentu. Evaluasi pembelajaran merupakan penilaian kegiatan dan kemajuan belajar siswa yang dilakukan secara berkala berbentuk ujian, hasil praktik, tugas harian, atau pengamatan oleh guru.

Peran siswa dalam pembelajaran merupakan unsur manusiawi yang penting dalam kegiatan interaksi edukatif. Menurut Khodijah (2011, p.181) perbedaan individual di antara anak didik merupakan hal yang tidak mungkin dihindari, karena hampir tidak ada kesamaan yang dimiliki oleh manusia kecuali perbedaan itu sendiri. Sejauh mana individu berbeda akan mewujudkan kualitas perbedaan mereka atau kombinasi-kombinasi dari berbagai unsur perbedaan tersebut.

Menurut Khodijah (2011, p.182) perbedaan individual yang dimiliki anak didik antara lain meliputi perbedaan dalam aspek biologis, psikologis, intelegensi, bakat, dan perbedaan lainnya.

Dalam dunia pendidikan, Sanjaya (2006, p.126) menyebutkan bahwa strategi diartikan sebagai perencanaan yang berisi tentang rangkaian kegiatan yang didesain untuk mencapai tujuan pendidikan tertentu.

Berlangsungnya pembelajaran tidak terlepas dari strategi pembelajaran yang akan diterapkan. Komponen-komponen pada strategi pembelajaran menurut Dick \& Carey (2001, p.189) terdiri dari tahapan atau kegiatan pembelajaran, media pembelajaran, metode pembelajaran, waktu dan pengelolaan kelas.

Kegiatan pembelajaran dapat memudahkan guru dalam pelaksanaan kegiatan mengajarnya, guru dapat mengetahui bagaimana harus memulai, menyajikan dan menutup pelajaran. Kegiatan pembelajaran tersebut dapat dilihat pada Rencana Pelaksanaan Pembelajaran (RPP).

Metode pembelajaran menurut Sudjana (2009, p.76) adalah cara yang digunakan guru dalam mengadakan interaksi atau hubungan dengan siswa pada saat berlangsungnya pembelajaran. Berkaitan dengan penelitian ini metode dalam pembelajaran membuat pola sesuai desain menggunakan metode demonstrasi dan pemberian tugas yang diterapkan pada strategi pembelajaran dengan media berbasis komputer adobe flash.

Kata media bentuk jamak dari perantara (medium) merupakan sarana komunikasi. Berasal dari bahasa latin medium, istilah ini untuk merujuk pada apa saja yang membawa informasi antara sebuah sumber dan penerima (Sharon et al, 2012, p.7).

Sementara itu, Kemp \& Dayton (1985, p.3) menjelaskan media pembelajaran sebagai berikut : 
Instructional media also make use at the power of pictures, words and sounds to compel attention, to help an audience understand ideas and acquire information to complex for verbal explanation alone, and to help over come the limitation of time, size, and space.

Media pembelajaran adalah penggunaan gambar, tulisan dan suara untuk meningkatkan perhatian, membantu siswa mamahami ide dan mendapatkan informasi yang sangat kompleks yang memerlukan penjelasan tersendiri, dan membantu mengatasi keterbatasan waktu, ukuran dan tempat.

Secara umum manfaat media pembelajaran menurut Harjanto (1997, p.245) adalah : (a) memperjelas penyajian pesan agar tidak terlalu verbalistis (tahu kata-katanya, tetapi tidak tahu maksudnya), (b) mengatasi keterbatasan ruang, waktu dan daya indera, (c) dengan menggunakan media pembelajaran yang tepat dan bervariasi dapat diatasi sikap pasif siswa, dan (d) dapat menimbulkan persepsi yang sama terhadap suatu masalah.

Dalam memilih media untuk penelitian ini, peneliti memperhatikan beberapa hal, yaitu: (a) komunikatif, media tersebut dibuat sekomunikatif munkin, (b) harga terjangkau, harga disesuaikan dengan kemampuan masing-masing sekolah, (c) nilai kepraktisan, kepraktisan dalam penggunaanny, dan (d) kondisi pemakainya, bagaimana kemampuan guru dan siswa dalam menggunakan komputer.

Pengajar harus mengetahui alokasi waktu yang diperlukan dalam menyelesaikan pembelajaran dan waktu yang digunakan pengajar dalam menyampaikan informasi pembelajaran. Sehingga proses pembelajaran berjalan sesuai dengan target yang ingin dicapai. Pengelolaan kelas merupakan cara yang ditempuh oleh guru dalam menciptakan lingkungan kelas agar tidak terjadi kekacauan dan memberi kesempatan kepada peserta didik untuk mencapai tujuan akademis dan sosial.

Pembelajaran berbasis komputer adalah pembelajaran yang menggunakan komputer sebagai alat bantu (Wena, 2011, p.203). Media pembelajaran berbasis komputer yang akan digunakan untuk pembelajaran membuat pola adalah media adobe flash dan media power point. Kedua media tersebut meruapakan media berbasis komputer, sehingga ada beberapa aspek yang perlu diperhatikan dalam proses pengembangan kedua media tersebut, yaitu:Teks, warna, audio, gambar dan animasi

Flash CS 3 Profesional merupakan salah satu produk Macromedia penyedia aplikasi pembuatan animasi dan web. Dibanding program-program animasi lain, program Adobe Flash CS 3 Profesional lebih fleksibel dalam pembuatan animasi dengan menyediakan berbagai hal baru sebegai penyempurna fitur-fitur pada versi sebelumya (Madcoms, 2008, p.1).

Sedangkan power point adalah suatu program untuk menyusun presentasi dengan beragam fasilitas dan fitur yang ramah pengguna (user friendly) sehingga memudahkan pemakainya (Wahana Komputer, 2010, p.2).

Kompetensi dalam konteks pengembangan kurikulum, menurut Sanjaya (2006,p.68) adalah perpaduan dari pengetahuan, ketrampilan, nilai, dan sikap yang direfleksikan dalam kebiasaan berfikir dan bertindak. Seseorang yang memiliki kompetensi tertentu bukan hanya mengetahui, tetapi juga dapat memahami dan menghayati bidang tersebut yang tercermin dalam pola perilaku sehari-hari.

Grinffin (2007, p.22) menyatakan bahwa "competence has been generally defined as the capacity to meet the standard of performance expected in the workplace". Kompetensi pada dasarnya merupakan gambaran yang sebaiknya dapat dilakukan sesorang dalam suatu pekerjaan. Agar dapat mengerjakan sesuatu dalam pekerjaannya, seseorang harus memiliki kemampuan tentang pengetahuan, ketrampilan dan sikap.

Dalam kurikulum SMK kompetensi mengandung makna kemampuan seseorang yang disyaratkan dalam menyelesaikan pekerjaan tertentu pada dunia kerja dan ada pengakuan resmi atas kemampuan tersebut. Kompetensi lulusan merupakan kualifikasi kemampuan lulusan yang mencakup sikap (afektif), pengetahuan (kognitif) dan keterampilan (psikomotorik) sesuai dengan standar nasional yang telah disepakati (UU No. 2003 tentang Sisdiknas pasal 35 ayat 1$)$.

Sebagaimana dikemukakan oleh Bloom dalam Hanafiah dan Suhana (2009, pp.20-23) 
aspek kognitif, afektif dan psikomotor dapat dilihat sebagai berikut : (1) Aspek kognitif mencakup : ingatan atau pengetahuan (knowledge), pemahaman (comprehension), penerapan (application), analisis (analisys), sintesis (synthesis), penilaian (evaluation). (2) Aspek afektif mencakup: penerimaan (receiving), penanggapan (responding), penghargaan ( $\mathrm{va}$ luing), pengorganisasian (organization), pengkarakterisasian (characterization). (3) Aspek psikomotor mencakup: persepsi (perception), kesiapan (set), respon terbimbing (guide respons), mekanisme (mechanism), respons nyata kompleks (complex over respons), penyesuaian (adaptation), penciptaan (origination).

Penilaian kompetensi melalui penilaian pembelajaran praktik merupakan hal yang harus dilaksanakan untuk mengetahui sejauh mana penguasaan kompetensi siswa. Penilaian pembelajaran yang bersifat ketrampilan tidak hanya pada hasil atau produk ketrampilan yang dibuat saja, tetapi serangkaian proses pembuatannya karena dalam pembelajaran ketrampilan kompetensi dasar meliputi seluruh aspek kegiatan, produksi dan refleksi. Untuk melihat hasil kompetensi siswa diperlukan penilaian yang mencakup ketiga aspek tersebut.

Karakteristik penilaian berbasis kompetensi merupakan suatu bentuk penilaian yang mengacu pada tujuan, baik tujuan umum maupun tujuan khusus, dimana guru sebagi penilai dapat memberikan penilaian yang cukup obyektif berkaitan dengan pencapaian kompetensi sesuai dengan tujuan yang telah dirumuskan. Penilaian berbasis kompetensi adalah cara yang digunakan oleh para pengajar untuk mengevaluasi kinerja siswanya untuk tujuan penempatan dan perencanaan pengembangan profesional (Yorkovich, 2008, p.1).

Pola sangat penting dalam membuat busana, baik tidaknya busana yang dikenakan seseorang sangat dipengaruhi oleh kebenaran pola itu sendiri. Dapat diartikan bahwa pola-pola busana yang berkualitas akan menghasilkan busana yang nyaman diapakai, indah dipandang dan bernilai tinggi, sehingga akan tercipta suatu kepuasan bagi si pemakai.

Pengertian pola menurut Assembil (2013,p.1) yakni:
Patterns are essentially a 2D template that represents the shape that will be cut out in fabric. A pattern is normally laid on top of the fabric, and the fabric is cut to follow the outline of the pattern.

Pola pada dasarnya adalah contoh 2 dimensi yang mewakili bentuk yang akan digunakan acuan untuk memotong kain. Sebuah pola biasanya diletakkan di atas kain, dan kain dipotong mengikuti garis besar pola.

Sebagaimana dinyatakan oleh Assembil (2013:2) :

Patterns are so useful and important because they allow a designer's idea to become repeatable. Patterns allow for a correct result to be reached time and time again, and it is important to think of them in this way. Whether you are writing instructions and markings on patterns for yourself to use in the future or for someone else to follow, they must be easy to understand so that the same result can always be reached without any mistakes.

Pola sangat berguna dan penting karena pola memungkinkan ide seorang desainer untuk bisa digunakan berulang. Dengan membuat pola memungkinkan hasil yang benar dalam mencapai waktu yang efektif, dan penting untuk memikirkan membuat pola dengan cara ini. Apabila menulis petunjuk dan tanda-tanda pada pola sendiri untuk digunakan di masa depan atau untuk orang lain untuk diikuti, maka pola harus mudah dipahami sehingga hasil yang sama selalu dapat dicapai tanpa kesalahan.

Berdasarkan pendahuluan yang telah dijelaskan di atas, maka penelitian ini bertujuan untuk mengetahui : (1) Perbedaan pencapaian kompetensi siswa dalam membuat pola sesuai desain di SMK N 6 Yogyakarta yang menggunakan strategi pembelajaran berbantuan media adobe flash dengan power point. (2) Perbedaan pencapaian kompetensi siswa dalam membuat pola sesuai desain di SMK N 6 Yogyakarta pada siswa berkemampuan tinggi yang menggunakan strategi pembelajaran berbantuan media adobe flash dengan power point. (3) Perbedaan pencapaian kompetensi siswa dalam membuat pola sesuai desain di SMK N 
Tabel 1. Desain Penelitian

\begin{tabular}{ccc}
\hline Kelas & Perlakuan (Treatment) & Kompetensi \\
\hline $\mathrm{G}_{1}$ & $\mathrm{X}$ & $\mathrm{O}_{1}$ \\
$\mathrm{G}_{2}$ & - & $\mathrm{O}_{2}$ \\
\hline
\end{tabular}

Keterangan :

$\mathrm{G}_{1}$ : kelas eksperimen

$\mathrm{G}_{2}$ : kelas kontrol

$\mathrm{X}$ : pembelajaran dengan media adobe flash

- : pembelajaran dengan media power point

$\mathrm{O}_{1}$ : kelas eksperimen setelah diberi perlakuan

$\mathrm{O}_{2}$ : kelas kontrol yang tidak diberi perlakuan

6 Yogyakarta pada siswa berkemampuan rendah yang menggunakan strategi pembelajaran berbantuan media adobe flash dengan power point. (4) Interaksi penggunaan strategi pembelajaran berbantuan media berbasis komputer dan kemampuan siswa terhadap kompetensi siswa dalam membuat pola sesuai desain kelas XI di SMK N 6 Yogyakarta.

Manfaat yang diharapkan setelah melaksanakan penelitian ini bagi siswa, agar dapat digunakan sebagai umpan balik dalam memotivasi diri untuk meningkatkan prestasi belajar, khususnya pada mata diklat membuat pola. Bagi guru dan calon guru, pembelajaran berbantuan media berbasis komputer adobe flash ini dapat diterapkan pada proses pembelajaran praktek membuat pola sesuai desain. Bagi mahasiswa sebagai peneliti, penelitian ini diharapkan menjadi bahan kajian maupun referensi ilmiah dalam bidang pendidikan, juga dapat menjadi bahan penelitian lanjutan mengenai permasalahan sejenis dengan hasil yang lebih baik. Bagi sekolah, penelitian ini dapat digunakan sebagai masukan positif terhadap kemajuan sekolah sebagai usaha untuk meningkatkan mutu pendidikan melalui pemanfaatan TIK.

\section{METODE PENELITIAN}

\section{Desain Penelitian}

Penelitian ini merupakan penelitian quasi eksperimen dengan variabel terikat kompetensi siswa membuat pola, variabel bebas media pembelajaran berbasis komputer, dan variabel moderator kelompok kemampuan siswa.

\section{Waktu dan Tempat Penelitian}

Penelitian dilaksanakan di SMK Negeri 6 Yogyakarta yang beralamat di jalan Kenari No. 4 Umbulharjo Yogyakarta dan dilaksanakan pada bulan November 2013.

\section{Subjek Penelitian}

Subyek penelitian ini adalah seluruh siswa kelas XI Busana Butik SMK Negeri 6 Yogyakarta yang terdiri dari tiga kelas. Pemilihan sampel dilakukan secara acak 2 kelas (XI BB 2 sebagai kelas eksperimen dan XI BB 3 sebagai kelas kontrol) kemudian dikelompok-kan secara semu berdasarkan kemampaun siswa tinggi dan rendah, dengan 22 siswa pada masing-masing kelas, sehingga jumlah keseluruhan adalah 44 siswa.

\section{Prosedur}

Penelitian quasi eksperimen ini terdiri dari dua faktor, yaitu faktor pemilihan media pembelajaran berbasis komputer (media adobe flash dan media power point) dan faktor kelompok kemampuan siswa (kelompok tinggi dan rendah). Pemilahan kelompok dibagi atas dua tingkatan yaitu kelompok tinggi di atas rata-rata kelas (33,3 \% dari atas) dan kelompok rendah di bawah rata-rata kelas $(33,3 \%$ dari bawah) setelah data diurutkan dari yang paling besar ke yang paling kecil.

Dalam pelaksanaan penelitian ini, pemisahan kelompok belajar siswa bersifat semu artinya dalam kegiatan eksperimen, para siswa tidak dipisahkan secara nyata antara yang memiliki kemampuan belajar tinggi dan kemampuan belajar rendah. Rancangan analisis penelitian quasi eksperimen dapat dilihat pada tabel 2. 
Tabel 2. Rancangan Analisis Penelitian

\begin{tabular}{lccc}
\hline \multirow{2}{*}{ Kemampuan Siswa } & \multicolumn{2}{c}{ Media Pembelajaran } & \multirow{2}{*}{ Total } \\
\cline { 2 - 3 } & Adobe Flash $(\mathrm{X})$ & Power Point $(\mathrm{Y})$ & \\
\hline Tinggi (1) & $\overline{\mathrm{X}}_{\mathrm{X} 1}$ & $\overline{\mathrm{X}}_{\mathrm{Y} 1}$ & $\overline{\mathrm{X}}_{\mathrm{X} 1}+\overline{\mathrm{X}}_{\mathrm{Y} 1}$ \\
Rendah(2) & $\overline{\mathrm{X}}_{\mathrm{X} 2}$ & $\overline{\mathrm{X}}_{\mathrm{Y} 2}$ & $\overline{\mathrm{X}}_{\mathrm{X} 2}+\overline{\mathrm{X}}_{\mathrm{Y} 2}$ \\
Total & $\overline{\mathrm{X}}_{\mathrm{X} 1}+\overline{\mathrm{X}}_{\mathrm{X} 2}$ & $\overline{\mathrm{X}}_{\mathrm{Y} 1}+\overline{\mathrm{X}}_{\mathrm{Y} 2}$ & \\
\hline
\end{tabular}

Keterangan:

$\overline{\mathrm{X}}_{\mathrm{X} 1}=$ Rata-rata kompetensi siswa yang belajar dengan media adobe flash pada kelompok tinggi

$\overline{\mathrm{X}}_{\mathrm{x}_{2}}=$ Rata-rata kompetensi siswa yang belajar dengan media adobe flash pada kelompok rendah

$\overline{\mathrm{X}}_{\mathrm{Y} 1}=$ Rata-rata kompetensi siswa yang belajar dengan media power point pada kelompok tinggi

$\overline{\mathrm{X}}_{\mathrm{Y} 2}=$ Rata-rata kompetensi siswa yang belajar dengan media power point pada kelompok rendah

\section{Intrumen dan Teknik Pengumpulan Data}

Instrumen pengumpulan data yang digunakan dalam penelitian ini yakni lembar penilaian unjuk kerja dan soal post test. Adapun rincian penggunaan dua instrumen tersebut adalah sebagai berikut. 1) penilaian unjuk kerja : untuk mengungkap data tentang unjuk kerja dan sikap siswa selama pelaksanaan pembelajaran membuat pola serta memberi penilaian kompetensi siswa pada ranah psikomotor dan afektif. Penilaian dilakukan dengan cara guru dan peneliti melakukan pengamatan terhadap setiap proese pembelajaran yang dilakukan siswa mulai dari persiapan alat dan bahan, proses pembuatan pola, hasil jadi pola, sikap siswa dan waktu; 2) soal post test : berupa test pilihan ganda untuk mengungkap sejauh mana pengetahuan siswa dalam membuat pola serta memberi penilaian kompetensi siswa pada ranah kognitif.

Penilaian kompetensi siswa dilakukan dengan kedua instrumen tersebut, dengan pembagian bobot $70 \%$ untuk penilaian unjuk kerja dan $30 \%$ untuk post test siswa. Pembobotan tersebut berdasarkan pembobotan penilaian yang dilakukan oleh guru pada mata diklat Membuat Pola di SMK N 6 Yogyakarta. Pembobotan pada penilaian unjuk kerja jauh lebih tinggi dikarenakan proses pembelajaran yang dilakukan adalah pembelajaran praktek sehingga diperlukan penilaian kompetenisi siswa dari awal hingga akhir pembelajaran membuat pola.

\section{Teknik Analisis Data}

Teknik analisis data yang digunakan pada penelitian ini bersifat kuantitatif yakni statistik deskriptif dan statistik inferensial. Pada statistik deskriptif dikemukakan cara penyajian data dengan tabel maupun distribusi frekuensi, penjelasan kelompok melalui mean, median, modus, standar deviasi dan variasi kelompok dan histogram.

Analisis pada penilaian unjuk kerja yang mengukur pada aspek psikomotor dan afektif terbagi menjadi 5 point utama yaitu persiapan, proses, hasil, sikap kerja dan waktu. Penilaian unjuk kerja terdiri dari 14 butir yang masingmasing dengan strategi skala perbedaan dimana skor yang diberikan 4, 3, 2, dan 1 .

Sedangkan analisis pada lembar soal post test untuk mengukur aspek kognitif atau pengetahuan siswa dengan bentuk soal pilihan ganda, terdiri dari 20 butir soal yang masingmasing strategi skala perbedaan dimana skor yang diberikan sama pada setiap butir soal.

Statistik inferensial digunakan untuk menguji hipotesis penelitian. Uji Hipotesis yang digunakan pada penelitian ini yaitu dengan uji Anava jalur ganda untuk menjawab hipotesis 1 dan 4 dan uji lanjut Tukeys untuk menjawab hipotesis 2 dan 3. 
Tabel 3. Deskripsi Data Kompetensi Siswa

\begin{tabular}{|c|c|c|c|c|}
\hline \multirow{2}{*}{ Kemampuan Siswa } & \multirow{2}{*}{ Statistik } & \multicolumn{2}{|c|}{ Media Pembelajaran } & \multirow{2}{*}{$\begin{array}{c}\text { Gabungan } \\
\mathbf{A}+\mathbf{P}\end{array}$} \\
\hline & & Adobe Flash (A) & Power Point (P) & \\
\hline \multirow[t]{6}{*}{ Tinggi $(\mathrm{T})$} & $\mathrm{n}$ & 11 & 11 & 22 \\
\hline & $\bar{X}$ & 87,8 & 82,57 & 85,185 \\
\hline & $\mathrm{S}^{2}$ & 8,26 & 6,34 & 7,3 \\
\hline & $\mathrm{X}_{\text {terendah }}$ & 83,4 & 78,1 & 78,1 \\
\hline & $X_{\text {tertinggi }}$ & 92,6 & 86 & 92,6 \\
\hline & $\mathrm{X}_{\max }$ & 100 & 100 & 100 \\
\hline \multirow[t]{7}{*}{ Rendah (R) } & $\mathrm{n}$ & 11 & 11 & 22 \\
\hline & $\overline{\mathrm{X}}$ & 75,95 & 76 & 75,975 \\
\hline & $\mathrm{S}^{2}$ & 19,94 & 21,65 & 20,795 \\
\hline & $X_{\text {terendah }}$ & 67,6 & 69,9 & 67,6 \\
\hline & $X_{\text {tertinggi }}$ & 81,7 & 83,9 & 83,9 \\
\hline & $\mathrm{X}_{\max }$ & 100 & 100 & 100 \\
\hline & $\mathrm{n}$ & 22 & 22 & 44 \\
\hline \multirow[t]{5}{*}{ Gabungan $\mathrm{T}+\mathrm{R}$} & $\bar{X}$ & 81,875 & 79,285 & 80,58 \\
\hline & $\mathrm{S}^{2}$ & 14,1 & 13,995 & 14,0475 \\
\hline & $X_{\text {terendah }}$ & 67,6 & 69,9 & 67,6 \\
\hline & $X_{\text {tertinggi }}$ & 92,6 & 86 & 92,6 \\
\hline & $\mathrm{X}_{\max }$ & 100 & 100 & 100 \\
\hline
\end{tabular}

\section{HASIL PENELITIAN DAN PEMBAHASAN}

SMK Negeri 6 Yogyakarta adalah salah satu Sekolah Menengah Kejuruan yang telah lama berdiri dan mempunyai program studi Busana Butik. Program studi Busana Butik memiliki 9 kelas yaitu setiap angkatan memiliki 3 kelas. Kelas yang digunakan untuk penelitian yaitu kelas XI, karena merupakan kelas yang mendapatkan materi membuat pola sesuai desain.

SMK Negeri 6 Yogyakarta mempunyai visi dan misi menghasilkan lulusan yang berakhlak mulia, bermental kuat, berprestasi tinggi, profesional dan tangguh dalam persaingan akademik maupun dunia kerja, dengan mengembangkan nilai-nilai seperti: Unggul dalam kegiatan Keagamaan, Pariwisata, Disiplin, Olah Raga dan Seni, Bahasa Asing, Lingkungan Hidup, Keterserapan Tamatan dan Misi profesional dalam penyelenggaraan pendidikan berbasis produktif: a) Menciptakan etos kerja yang Produktif Mengembangkan sikap; b) Dedikatif terhadap profesi yang ditekuni, Membangun dan mempertahankan; c) Unjuk kerja yang tinggi; d) Mengembangkan kreativitas dalam memanfaatkan peluang pasar. Adaptif dalam menyikapi perkembangan ilmu pengetahuan dan dunia bisnis.

Setelah memaparkan gambaran singkat SMK N 6 Yogyakarta, selanjutnya temuan akan disajikan dan dibahas sesuai dengan rancangan quasi eksperimen yang digunakan. Data pencapaian kompetensi siswa terbagi menjadi empat kelompok kecil berdasarkan strategi pembelajaran berbantuan media berbasis komputer dan kemampuan awal siswa. Keempat kelompok tersebut yaitu data kompetensi siswa membuat pola dengan media pembelajaran adobe flash kemampuan siswa tinggi, kompetensi siswa membuat pola dengan media pembelajaran adobe flash kemampuan siswa rendah, kompe- 


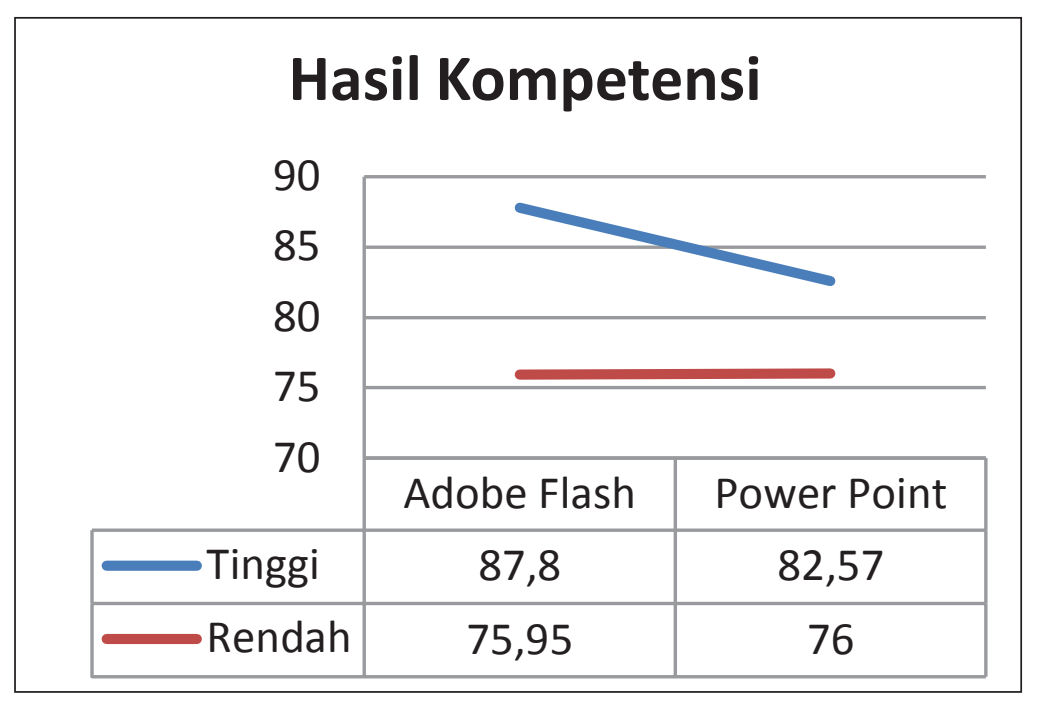

Gambar 1. Diagram Rerata Kompetensi Siswa

tensi siswa membuat pola dengan media pembelajaran power point kemampuan siswa tinggi dan kompetensi siswa membuat pola dengan media pembelajaran power point kemampuan siswa rendah.

Hasil kompetensi siswa dalam membuat pola pada keempat kelompok tersebut dapat dilihat pada tabel .

Berdasarkan tabel di atas dapat dinyatakan bahwa nilai kompetensi siswa membuat pola sesuai desain pada kelas eksperiman atau kelas yang diberi perlakuan diperoleh nilai tertinggi sebesar 92,6, nilai terendah sebesar 67,6 dan nilai rata-rata sebesar 81,875 .

Kompetensi siswa membuat pola sesuai desain pada kelas eksperimen dengan kemampuan belajar siswa tinggi diperoleh nilai tertinggi sebesar 92,6, nilai terendah sebesar 83,40 dan nilai rata-rata sebesar 87,80 . Nilai tersebut jauh lebih tinggi apabila dibandingkan dengan kemampuan siswa rendah diperoleh nilai tertinggi sebesar 81,70 , nilai terendah sebesar 67,6 dan nilai rata-rata sebesar 75,95.

Berdasarkan tabel di atas pula dapat dinyatakan bahwa nilai kompetensi siswa membuat pola sesuai desain pada kelas kontrol atau kelas yang tidak diberi perlakuan diperoleh nilai tertinggi sebesar 86,0 , nilai terendah sebesar 69,9 dan nilai rata-rata sebesar 79,285.

Kompetensi siswa membuat pola sesuai desain pada kelas kontrol dengan kemampuan belajar siswa tinggi diperoleh nilai tertinggi sebesar 86,0, nilai terendah sebesar 78,1 dan nilai rata-rata sebesar 82,57 . Nilai tersebut lebih tinggi apabila dibandingkan dengan kemampuan siswa rendah diperoleh nilai tertinggi sebesar 83,90, nilai terendah sebesar 69,90 dan nilai rata-rata sebesar 76,0 .

Sementara itu, dengan membandingkan rata-rata kompetensi siswa membuat pola pada kelompok strategi pembelajaran adobe flash dan power point, dan tingkat kemampuan belajar siswa tinggi dan rendah. Berikut ini diagram yang menunjukkan rerata hasil kompetensi siswa pada masing-masing kelompok.

Diagram hasil rata-rata kompetensi siswa di atas, maka dapat dilihat bahwa nilai rata-rata pada kelompok strategi pembelajaran adobe flash dengan kemampuan siswa tinggi lebih tinggi daripada nilai rata-rata pada kelompok strategi pembelajaran power point dengan kemampuan siswa tinggi $(87,8>82,57)$. Namun sebaliknya pada nilai rata-rata pada kelompok strategi pembelajaran adobe flash dengan kemampuan siswa rendah justru lebih rendah atau dapat dikatakan hampir sama dengan nilai rata-rata pada kelompok strategi pembelajaran power point dengan kemampuan siswa rendah $(75,95<76,0)$.

Berdasarkan deskripsi data tersebut selanjutnya dilaksanakan uji hipotesis penelitian menggunakan ANAVA jalur ganda. Hasil dari uji hipotesis tersebut dapat dilihat pada tabel 4. 
Tabel 4. Ringkasan Hasil ANAVA 2 Jalur

\begin{tabular}{lccccc}
\hline Sumber Varian & $\mathbf{d k}$ & Jumlah Kuadrat & Mean Kuadrat & $\mathbf{F}_{\mathbf{0}}$ & $\mathbf{F}_{\mathbf{t : a}=\mathbf{0}, \mathbf{0} 5}$ \\
\hline Media Pembelajaran (A) & 1 & 73,84 & 73,84 & 5,26 & 4,08 \\
Kemampuan Siswa (B) & 1 & 932,88 & 932,88 & 66,43 & 4,08 \\
Interaksi (A x B) & 1 & 76,45 & 76,45 & 5,44 & 4,08 \\
Dalam & 40 & 561,71 & 14,04 & & \\
Total & 43 & 1644,89 & & & \\
\hline
\end{tabular}

Tabel 5. Hasil Uji Tukey's

\begin{tabular}{lcccc}
\hline Perlakuan & $\mathbf{q}_{\mathbf{o}}$ & $\mathbf{q}_{\mathbf{t} \mathbf{a}=\mathbf{0}, \mathbf{0 5}}$ & HSD & Hasil \\
\hline A - P & 2,590 & 2,86 & 2,285 & Signifikan \\
T - R & 9,209 & 2,86 & 2,285 & Signifikan \\
AT - PT & 5,230 & 3,79 & 4,282 & Signifikan \\
AR - PR & $-0,040$ & 3,79 & 4,282 & Tidak Signifikan \\
\hline
\end{tabular}

Keterangan:

$\mathrm{A}-\mathrm{P}=$ menguji perbedaan kompetensi siswa membuat pola yang menggunakan strategi pembelajaran media adobe flash dan power point

$\mathrm{T}-\mathrm{R}=$ menguji perbedaan kompetensi siswa membuat pola yang memiliki kemampuan tinggi dengan kemampuan rendah

AT-PT $=$ menguji perbedaan kompetensi siswa membuat pola yang memiliki kemampuan tinggi menggunakan strategi pembelajaran media adobe flash dan power point

AR-PR = menguji perbedaan kompetensi siswa membuat pola yang memiliki kemampuan rendah menggunakan strategi pembelajaran media adobe flash dan power point

Dari hasil perhitungan uji Tukey’s, yaitu uji lanjut setelah uji ANAVA, dibuat tabel hasil pengujian untuk setiap kelompok sel pasangannya dapat dilihat pada tabel 5 .

Terdapat Perbedaan Pencapaian Kompetensi Siswa Membuat Pola Sesuai Desain Yang Menggunakan Strategi Pembelajaran Media Adobe Flash Dan Power Point.

Berdasarkan hasil uji Anova jalur ganda perbedaan pencapaian kompetensi siswa membuat pola yang menggunakan strategi pembelajaran media Adobe Flash dan Power Point dengan membandingkan nilai $\mathrm{F}$ hitung yakni 5,258 dengan $\mathrm{F}$ tabel, yakni $\mathrm{F}$ tabel $=4,08$ untuk $5 \%$. Hasil uji Anova diketahui bahwa $\mathrm{F}$ hitung lebih besar dari $\mathrm{F}$ tabel $(5,258>4,08)$ sehingga dapat disimpulkan bahwa Ho ditolak dan Ha diterima. Hal tersebut berarti terdapat perbedaan yang signifikan antara pencapaian kompetensi siswa membuat pola yang menggunakan strategi pembelajaran media Adobe Flash dan Power Point.
Hasil dalam penelitian ini menunjukkan bahwa strategi pembelajaran dengan media adobe flash memberikan pengaruh yang berbeda dari strategi pembelajaran dengan media power point ditinjau dari pencapaian kompetensi siswa membuat pola. Perbedaan pencapaian kompetensi tersebut tampak pada rerata kompetensi siswa membuat pola pada kelas eksperimen (adobe flash) lebih tinggi daripada kelas kontrol (power point).

Dari kedua strategi pembelajaran tersebut, media adobe flash mempunyai kemampuan lebih dibandingkan dengan media power point. Adobe flash mampu menggabungkan aspek teks, warna, audio, gambar dan animasi yang tayangannya bisa menjadi lebih nyata dan lebih jelas. Secara teori belajar akan lebih mudah ketika mereka telah mengikuti tahapan pengalaman nyata.. Dengan media adobe flash, setiap langkah dalam pembuatan pola sesuai desain dapat terlihat dengan jelas, dinamis dan runtut sehingga memudahkan siswa untuk memahami materi pembelajaran. 
Terdapat Perbedaan Pencapaian Kompetensi Siswa Membuat Pola Pada Kelompok Tinggi Yang Menggunakan Strategi Pembelajaran Media Adobe Flash Dan Power Point.

Berdasarkan hasil uji Tukey's pada baris AT-PT yakni menguji perbedaan kompetensi siswa membuat pola yang memiliki kemampuan tinggi menggunakan strategi pembelajaran media adobe flash dan power point dengan membandingkan nilai $\mathrm{q}_{\mathrm{o}}$ yang diperoleh dengan HSD dapat diketahui bahwa $\mathrm{q}_{0}$ lebih besar dari $\operatorname{HSD}(5,230>4,282)$ sehingga dapat disimpulkan bahwa Ho ditolak dan Ha diterima. Hal tersebut berarti terdapat perbedaan yang signifikan antara pencapaian kompetensi siswa membuat pola pada kelompok tinggi yang menggunakan strategi pembelajaran media Adobe Flash dengan strategi pembelajaran media Power Point.

Hasil ini telah diduga sebelumnya, mengingat keunggulan media adobe flash dalam pembelajaran membuat pola dapat dinyatakan lebih efektif dibandingkan dengan media power point. Siswa pada kelompok tinggi akan lebih mudah menyerap materi pembelajaran dan mengikuti proses pembelajaran dengan media berbasis komputer khususnya pada media adobe flash yang menampilkan langkah-langkah membuat pola sesuai desain dengan runtut dan gerakan yang nyata.

Siswa dengan tingkat kemampuan tinggi akan cenderung memiliki keingintahuan yang lebih terhadap sesuatu hal yang baru khususnya dalam hal ini media pembelajaran yang digunakan yakni media berbasis komputer. Siswa memberikan waktu dan semangat yang lebih banyak untuk belajar membuat pola dengan media berbasis komputer adobe flash.

Tidak Terdapat Perbedaan Pencapaian Kompetensi Siswa Membuat Pola Pada Kelompok Rendah Yang Menggunakan Strategi Pembelajaran Media Adobe Flash Dan Power Point.

Berdasarkan hasil uji Tukey's pada baris AR - PR yakni menguji perbedaan kompetensi siswa membuat pola yang memiliki kemampuan rendah menggunakan strategi pembelajaran media adobe flash dan power point dengan membandingkan nilai $\mathrm{q}_{\mathrm{o}}$ yang diperoleh dengan HSD, dapat diketahui bahwa $\mathrm{q}_{\mathrm{o}}$ lebih kecil dari HSD $(-0,040>4,282)$, sehingga dapat disimpulkan bahwa Ho diterima dan Ha ditolak. Hal tersebut berarti tidak terdapat perbedaan yang signifikan antara pencapaian kompetensi siswa membuat pola pada kelompok rendah yang menggunakan strategi pembelajaran media Adobe Flash dengan Power Point.

Berdasarkan hasil uji hipotesis sebelumnya menunjukan bahwa keunggulan media adobe flash pada pembelajaran membuat pola lebih efektif dibandingkan dengan media power point. Namun pada kelompok kemampuan belajar rendah media adobe flash tersebut justru kurang menarik perhatian siswa. Siswa pada kelompok kemampuan belajar rendah cenderung kurang tertarik pada hal-hal baru atau teknologi baru khususnya media pembelajaran berbasis komputer adobe flash. Hal tersebut dapat dilihat pada rata-rata kompetensi siswa membuat pola sesuai desain kemampuan rendah yang diajar dengan strategi pembelajaran media adobe flash lebih rendah atau hampir sama dengan siswa yang belajar menggunakan strategi pembelajaran media power point.

Terjadi Interaksi Antara Penggunaan Strategi Pembelajaran Media Berbasis Komputer Dan Kemampuan Siswa Terhadap Kompetensi Siswa Membuat Pola

Berdasarkan hasil uji Anova jalur ganda pada baris Interaksi (AxB) dengan membandingkan nilai $\mathrm{F}$ hitung yang diperoleh dengan $\mathrm{F}$ tabel, dapat diketahui bahwa $\mathrm{F}$ hitung lebih besar dari $F$ tabel $(5,444>4,08)$ sehingga dapat disimpulkan bahwa Ho ditolak dan $\mathrm{Ha}$ diterima. Hal tersebut berarti terdapat interaksi penggunaan strategi pembelajaran dengan media berbasis komputer dan kemampuan belajar terhadap kompetensi siswa membuat pola.

Keunggulan media pembelajaran berbasis komputer dengan adobe flash yaitu dapat menyajikan langkah-langkah membuat pola disertai animasi-animasi yang menarik sehingga dapat meningkatkan pemahaman siswa dalam membuat pola. Selain itu untuk mengaktifkan proses pembelajaran khususnya pelajaran praktek selain menggunakan media pembelajaran juga diperlukan sebuah metode pembelajaran yang dapat merangsang pikiran pesera didik.

Penentuan kelompok kemampuan siswa dilakukan berdasarkan nilai siswa pada mata 
diklat membuat pola materi sebelumnya. Terdapat tiga pengelompokan berdasarkan kemampuan siswa, yaitu tinggi, rata-rata dan rendah. Pada penelitian ini pengelompokan yang digunakan adalah kelompok tinggi dan rendah.

Kedua faktor tersebut berinteraksi, ini berarti bahwa rata-rata kompetensi siswa membuat pola dengan media adobe flash lebih besar dibandingkan siswa dengan media power point, baik untuk siswa dengan kemampuan tinggi dan rendah. Selisih rata-rata kompetensi siswa membuat pola sesuai desain kelas adobe flash dengan kelas power point dapat dianggap sedikit lebih kecil atau hampir sama besarnya antara yang diperoleh siswa dengan kemampuan tinggi dan rendah. Kesimpulan ini menunjukkan keunggulan strategi pembelajaran media adobe flash dibandingkan strategi pembelajaran power point yang diterapkan untuk siswa dengan kemampuan tinggi.

\section{SIMPULAN DAN SARAN}

\section{Simpulan}

Terdapat perbedaan pencapaian kompetensi siswa membuat pola yang menggunakan strategi pembelajaran media adobe flash dan power point. Berdasarkan perbandingan ratarata kompetensi siswa pada kelas eksperimen lebih tinggi daripada kelas kontrol. Hal tersebut dikarenakan pada strategi pembelajaran dengan adobe flash memiliki karakteristik yang dinamis dalam langkah pembuatan pola sehingga memberi kemudahan kepada siswa dalam memahami materi yang diajarkan.

Terdapat perbedaan pencapaian kompetensi siswa membuat pola pada kelompok tinggi yang menggunakan strategi pembelajaran media adobe flash dan power point. Pada kemampuan siswa tinggi strategi pembelajaran media adobe flash memberikan pengaruh yang lebih baik daripada strategi pembelajaran media power point berdasarkan rata-rata kompetensi siswa. Tidak terdapat perbedaan pencapaian kompetensi siswa membuat pola pada kelompok rendah yang menggunakan strategi pembelajaran media adobe flash dan power point. Pada kemampuan siswa rendah strategi pembelajaran media adobe flash memberikan pengaruh yang sama dengan strategi pembelajaran media power point berdasarkan rata-rata kompetensi siswa.

Terdapat interaksi penggunaan strategi pembelajaran media berbasis komputer dan kemampuan belajar siswa terhadap kompetensi siswa membuat pola. Jika dicermati untuk masing-masing kemampuan, diperoleh fakta bahwa terdapat pengaruh gabungan (interaksi) antara strategi pembelajaran media berbasis komputer dan kemampuan siswa terhadap kompetensi siswa membuat. Rata-rata nilai kompetensi siswa pada strategi pembelajaran media adobe flash kemampuan tinggi lebih tinggi daripada rata-rata nilai kompetensi siswa pada strategi pembelajaran media power point kemampuan tinggi. Sedangkan rata-rata nilai kompetensi siswa pada strategi pembelajaran media adobe flash kemampuan rendah lebih rendah atau hampir sama dengan rata-rata nilai kompetensi siswa pada strategi pembelajaran media power point kemampuan rendah.

\section{Saran}

Bagi guru pemilihan strategi pembe-lajaran dalam praktik membuat pola khususnya strategi pembelajaran media berbasis komputer, dapat memberikan pengalaman baru bagi siswa dalam memahami materi. Dalam kaitannya dengan meningkatkan kompetensi siswa, guru perlu memperhatikan tingkat kemampuan belajar siswa sebagai dampak pembelajaran sebelumnya.

Bagi penelitian selanjutnya disarankan untuk mengkombinasikan strategi pembelajaran yang lainnya dalam meneliti pengaruh strategi pembelajaran berbasis komputer terhadap pencapaian kompetensi siswa.

\section{DAFTAR PUSTAKA}

Assembil Books. (2013). How Patterns Work:The Fundamental Principles of Pattern Making and Sewing in Fashion Design. Diambil pada tanggal 10 September 2013 dari www.assembil.com

Billet, S. (2011). Vocational Education Purposes, Traditions, And Prospects. New York : Springer 
Dick, W., Carey, L., \& Carey, J.O.,(6 $6^{\text {th }}$ ed.). (2006). The Systematic Design of Instruction. New York : Addison-Wesley Educational Publisher

Griffin, P., Gillis, S. \& Calvito, L. (2007). Standards-Referenced Assessment For Vocational Education And Training In Schools. Australian Journal of Education. Vol. 51, No I, 2007, 19-38 Assessment Research Centre The University of Melbourne

Hanafiah, N. \& Suhana, C. (2009). Konsep Strategi Pembelajaran. Bandung : Refika Aditama

Hardjanto. (1997). Perencanaan Pengajaran. Jakarta: Rineka Cipta

Lucas, B., Spencer E., \& Claxton G. (2012). How To Teach Vocational Education: A Theory Of Vocational Pedagogy. Centre for Real-World learning: University of Winchester

Madcoms (2008). Adobe Flash CS 3 Profesional. Yogyakarta : Andi Publisher

Nitko, A. J., \& Brookhart, S.M. (2007). Educational Assessment of Students. Upper Saddle River, NJ: Pearson Education, Inc.
Sanjaya, W. (2006). Strategi Pembelajaran Berorientasi Standar Proses Pendidikan. Jakarta: Kencana Prenada Media Group.

Sharon, S.E., Lowther, D.L., \& Russel, J.D. (2012). Instructional Technology and Media For Learning. (terjemahan Arif Rahman). Jakarta:Kencana Prenada Media Group

Sudjana, N. (2009). Penilaian Hasil Proses Belajar mengajar. Bandung: PT Remaja Rosdakarya.

Sukmadinata, N. S. (2002). Pengembangan Kurikulum: Teori dan Praktek. Bandung: PT Remaja Rosdakarya.

Wahana Komputer (2010). Microsoft Power Point 2010 untuk Presentasi Profesional dan Efektif. Yogyakarta : Andi Publisher

Wena, M. (2011). Strategi Pembelajaran Inovatif Kontemporer:Suatu Tinjauan Konseptual Operasional. Jakarta: Bumi Aksara

Yorkovich, S. A., Waddell, G.S., \& Gerwig, R.K. (2008). Competence-Based Assessment Systems : Encourage Toward A More Holistic Approach. Diambil pada tanggal 5 September 2013. 